\title{
Synthesis of -1,4-Linked Galactan Side-Chains of Rhamnogalacturonan I
}

Andersen, Mathias Christian Franch; Kracun, Stjepan; Rydahl, Maja; Willats, William; Clausen, Mads Hartvig

Published in:

Chemistry - A European Journal

Link to article, DOI:

10.1002/chem.201602197

Publication date:

2016

Document Version

Peer reviewed version

Link back to DTU Orbit

Citation (APA):

Andersen, M. C. F., Kracun, S., Rydahl, M., Willats, W., \& Clausen, M. H. (2016). Synthesis of -1,4-Linked Galactan Side-Chains of Rhamnogalacturonan I. Chemistry - A European Journal, 22(33), 11543-11548. https://doi.org/10.1002/chem.201602197

\section{General rights}

Copyright and moral rights for the publications made accessible in the public portal are retained by the authors and/or other copyright owners and it is a condition of accessing publications that users recognise and abide by the legal requirements associated with these rights.

- Users may download and print one copy of any publication from the public portal for the purpose of private study or research.

- You may not further distribute the material or use it for any profit-making activity or commercial gain

- You may freely distribute the URL identifying the publication in the public portal 


\title{
Synthesis of $\beta-1,4$-linked galactan side chains of rhamnogalacturonan I
}

\author{
Mathias C. F. Andersen, ${ }^{[a]}$ Stjepan K. Kračun, ${ }^{[b]}$ Maja G. Rydahl, ${ }^{[b]}$ William G. T. Willats, ${ }^{[b, c]}$ and Mads H. \\ Clausen*[a]
}

Abstract: The synthesis of linear- and $(1 \rightarrow 6)$-branched $\beta$ - $(1 \rightarrow 4)$-D-galactans, side chains of the pectic polysaccharide rhamnogalacturonan I is described. The strategy relies on iterative couplings of $n$-pentenyl disaccharides followed by a late stage glycosylation of a common hexasaccharide core. Reaction with a covalent linker and immobilization on NHS-modified glass surfaces allows for the generation of carbohydrate microarrays. The glycan arrays enables the study of protein-carbohydrate interactions in a high-throughput fashion, here demonstrated with binding to mAbs and CBMs.

The plant cell walls represent almost $50 \%$ of the biomass found in plants and are therefore one of the main targets for biotechnological research. ${ }^{[1,2]}$ Major motivators are their potential as a renewable energy source for transport fuels, as functional foods, and as a source of raw materials to generate chemical building blocks for industrial processes. ${ }^{[1,2]}$ Pectin is a class of highly complex polysaccharides found in the primary cell wall. The pectic matrix resists compressive forces, determines porosity, contributes to ionic status, and has important roles in the plant's defense mechanisms. ${ }^{[3]}$ Extracts of pectic polysaccharides from plants have important applications in the food industry as gelling agents and stabilizers and lately modified citrus pectin (MCP) have found application as potential anti-metastatic agents. ${ }^{[4,5]}$ The activity has been explained by MCP's ability to act as ligands for the important cancer biomarker, galectin-3. ${ }^{[6-8]}$

Three main types of pectic polysaccharides have been identified in plants, homogalacturonan $(\mathrm{HG})$, rhamnogalacturonan (RG) I and II. RG-I is a heteropolymer of alternating $\alpha$-linked L-rhamnose and D-galacturonic acid residues with extensive branching of galactans, arabinogalactans and arabinans (see Figure 1). The diverse branching makes it very challenging to address the function of individual components in living cells. Alternatively, structurally defined oligosaccharides can be used as models for the more complex polysaccharide components in order to investigate a range of properties such as cell wall biosynthesis and protein-carbohydrate interactions.

Our aim was to prepare well-defined fragments of RG-I and print them onto microarrays. This would allow high-throughput screening of binding properties towards carbohydrate binding proteins.

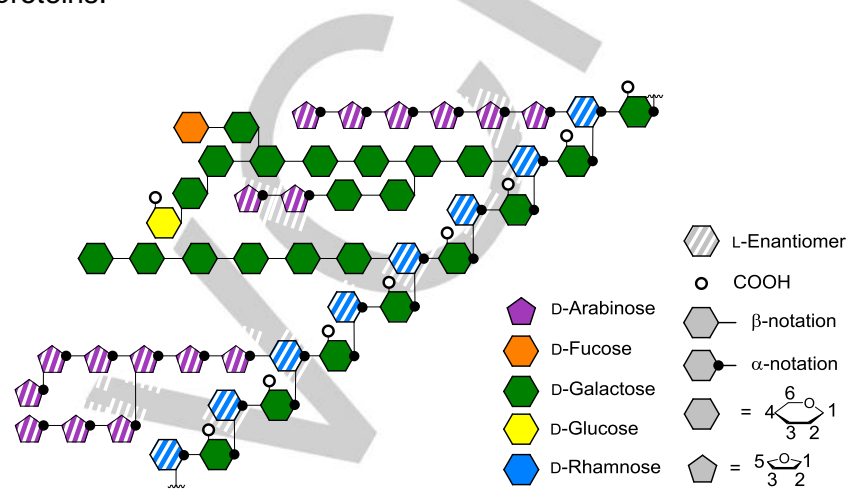

Figure 1. Schematic representation of the structure of RG-1

The synthesis of the RG-I backbone has been described in previous work. $^{[9]}$ This paper describes the synthesis of linear and branched galactans.

The chemical synthesis of $\beta-(1 \rightarrow 4)$-D-galactans is challenging due to the low reactivity of the axially disposed $\mathrm{C} 4-\mathrm{OH}$ of galactosyl acceptors. Not only are axial hydroxyls less accessible to glycosylation compared to primary and equatorial alcohols, but the acceptor must also typically ${ }^{10}$ be protected on the $\mathrm{C} 3-\mathrm{O}$ and $\mathrm{C} 6-\mathrm{O}$, thereby making the $\mathrm{C} 4-\mathrm{OH}$ even more sterically hindered. Thus, only three groups have reported syntheses of $\beta$-(1 $\rightarrow 4)$-D-galactooligosaccharides and two of them only reached the trisaccharide level. ${ }^{[11-13]}$

Our synthesis was based on a convergent strategy where a linear hexasaccharide with only one free hydroxyl was glycosylated with various glycosyl donors (Scheme 1). The linear hexasaccharide was prepared by consecutive glycosylations with an $n$-pentenyl disaccharide donor and the branching point was introduced via a NAP protected monosaccharide. The use of a disaccharide donor reduced the number of glycosylations and thereby improved the overall yield and reduced the number of steps.

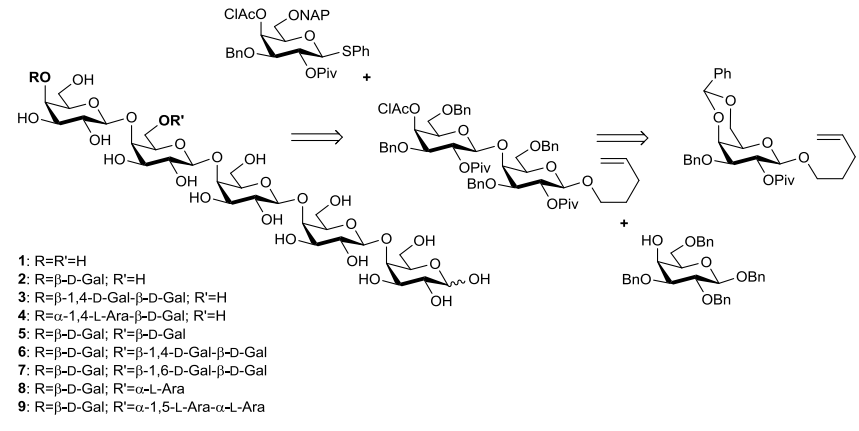

Scheme 1. Synthetic strategy. [a] Dr. M. C. F. Andersen \& Prof. Dr. Mads H. Clausen Center for Nanomedicine and Theranostics, ,Department of Chemistry, Technical University of Denmark, Kemitorvet, Building 207, DK-2800 Kgs. Lyngby, Denmark E-mail: mhc@kemi.dtu.dk

[b] Dr. S. K. Kračun, M. G. Rydahl, Prof. Dr. W. G. T. Willats Department of Plant and Environmental Sciences, Thorvaldsensvej 40, Frederiksberg C 1871, Denmark.

[c] Current address: School of Agriculture, Food and Rural Development, Newcastle University, Newcastle upon Tyne NE1 7RU, United Kingdom.

Supporting information for this article is given via a link at the end of the document. 
We have chosen to target reducing oligosaccharides and not install a synthetic linker at the reducing end of the target molecules 1-9. As the target molecules are fragments of larger polymers found in plant cell walls, they can serve as analytical standards for the oligosaccharides one obtains upon partial (chemo)enzymatic degradation of the polysaccharides. Furthermore, we have extensive experience with the covalent modification of reducing sugars in order to conjugate them to e.g. proteins and surfaces, techniques that we also take advantage of in this work (vide infra).

When we started investigating the reactivity of galactose acceptors, it was found to be crucial to protect the 3- and 6position with benzyl groups in order to facilitate glycosylations of the 4-position. The use of acyl protecting groups gave rise to low yield in glycosylations after the disaccharide stage. The 2-position was protected by a pivaloyl group to promote $\beta$-selectivity. Acetyl and benzoyl groups resulted in inferior $\alpha / \beta$-selectivity and formation of orthoesters. An $n$-pentenyl glycoside was chosen as disaccharide donor since glycosylation of thioglycoside acceptors with glycosyl imidates gave rise to transglycosylation of the thiophenyl moiety and thereby degradation of the acceptors through aglycon transfer.

The synthesis of the disaccharide donor and the monosaccharide for branching is shown in Scheme 2 . Regioselective benzylation of thioglycoside diol $\mathbf{1 0}$ followed by acylation of the $\mathrm{C} 2-\mathrm{OH}$ gave thioglycoside 12 . Regioselective reductive opening of the benzylidene acetal with $\mathrm{Et}_{3} \mathrm{SiH} / \mathrm{TFA}^{[14]}$ and treatment of the free $\mathrm{C} 4-\mathrm{OH}$ of 14 with $\mathrm{ClAc}_{2} \mathrm{O}, \mathrm{Et}_{3} \mathrm{~N}$ and DMAP provided the fully protected thioglycoside 16. Finally, hydrolysis with $\mathrm{NBS} / \mathrm{H}_{2} \mathrm{O}$ followed by treatment with $\mathrm{N}$-phenyl-trifluoroacetimidoyl chloride (PTFAICl) and $\mathrm{Cs}_{2} \mathrm{CO}_{3}$ gave the PTFAl donor $\mathbf{1 8}$ in $40 \%$ total yield over six steps. Careful control of the temperature was necessary, since formation of the $\alpha$-anomer was observed at higher temperatures $\left(-10^{\circ} \mathrm{C}\right)$. All of the reactions were easily scalable and it was possible to prepare disaccharide 20 on a $30 \mathrm{~g}$ scale.

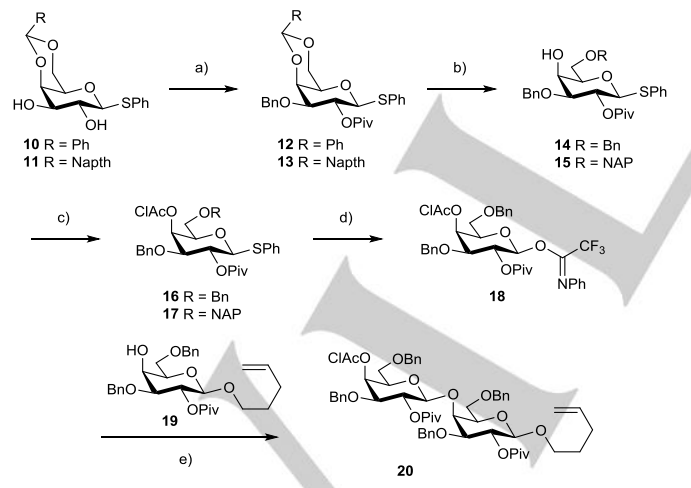

Scheme 2. a) i. $\mathrm{Bu}_{2} \mathrm{SnO}$ then $\mathrm{BnBr}$, TBAB, toluene ii. $\mathrm{PivCl}, \mathrm{Et}_{3} \mathrm{~N}, \mathrm{DMAP}$ $\mathrm{CH}_{2} \mathrm{Cl}_{2}$, 12: $77 \%$, 13: $75 \%$ b) $\mathrm{Et}_{3} \mathrm{SiH} / \mathrm{TFA}, \mathrm{CH}_{2} \mathrm{Cl}_{2}$, 14: $81 \%$ 15: $78 \% \mathrm{c}$ ) (ClAc) $)_{2} \mathrm{O}, \mathrm{Et}_{3} \mathrm{~N}, \mathrm{DMAP}, \mathrm{CH}_{2} \mathrm{Cl}_{2}, 16: 93 \%$ 17: $95 \%$ d) i. NBS, acetone $/ \mathrm{H}_{2} \mathrm{O}$, ii. PTFAICl, $\mathrm{Cs}_{2} \mathrm{CO}_{3}, \mathrm{CH}_{2} \mathrm{Cl}_{2}, 70 \%$ over two steps e) TMSOTf, $\mathrm{CH}_{2} \mathrm{Cl}_{2},-40{ }^{\circ} \mathrm{C}$, $83 \%$.

Disaccharide donor $\mathbf{2 0}$ was first applied in the synthesis of a linear $\beta$-(1 $\rightarrow 4)$-D-galactopentasaccharide and heptasaccharide (see Scheme 3). NIS/TESOTf-promoted coupling of acceptor $21^{[15]}$ and disaccharide donor 20 afforded trisaccharide 22 . This was converted to acceptor $\mathbf{2 3}$ by selective deprotection of the chloroacetyl group with $0.02 \mathrm{M} \mathrm{NaOMe}$ in $\mathrm{MeOH}$ at $0{ }^{\circ} \mathrm{C}$. The trisaccharide acceptor $\mathbf{2 3}$ was glycosylated with the disaccharide donor $\mathbf{2 0}$ to give pentasaccharide $\mathbf{2 4}$ in $\mathbf{8 3} \%$ yield. Deprotection with $\mathrm{NaOMe} / \mathrm{MeOH}$ followed by coupling with donor $\mathbf{2 0}$ gave the fully protected heptasaccharide 26 . The reaction was slower than the two previous glycosylations ( $3 \mathrm{~h}$ vs. $1 \mathrm{~h}$ ) but resulted in a similar yield.

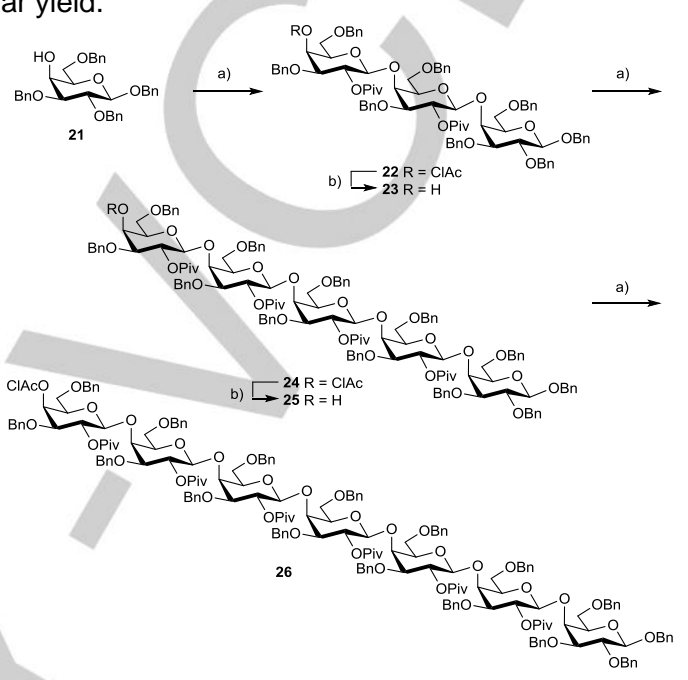

Scheme 3. a) 20, NIS/TESOTf, $\mathrm{MeCN} / \mathrm{CH}_{2} \mathrm{Cl}_{2},-40{ }^{\circ} \mathrm{C}, 22: 85 \%$, 24: $83 \%$, 26: $80 \%$ b) $\mathrm{NaOMe} / \mathrm{MeOH}, 0{ }^{\circ} \mathrm{C} \mathrm{23:} 91 \%$, 25: $93 \%$.

Global deprotection of the pentasaccharide and heptasaccharide was achieved by treatment with $\mathrm{Et}_{4} \mathrm{NOH}$ in refluxing THF followed by hydrogenolysis over $\mathrm{Pd}(\mathrm{OH})_{2} / \mathrm{C}$ to afford the fully unprotected oligosaccharides 1 and $\mathbf{3}$ in $72 \%$ and $78 \%$ yield, respectively (see Scheme 4).

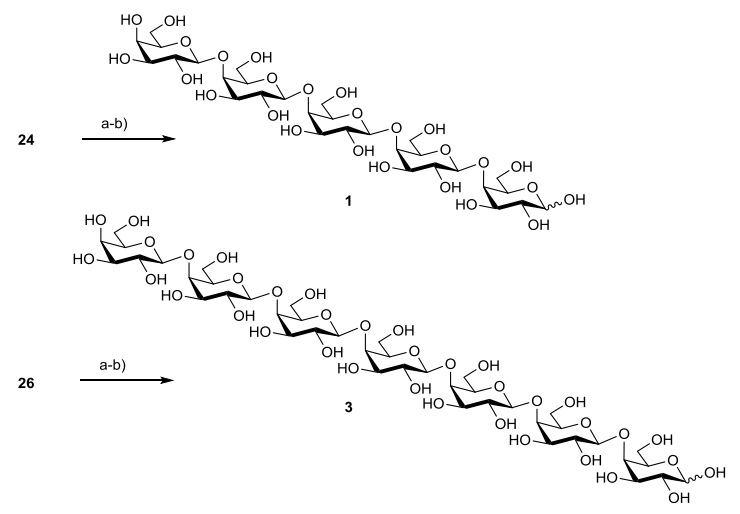

Scheme 4. a) $\mathrm{Et}_{4} \mathrm{NOH}, \mathrm{MeOH} / \mathrm{THF}, 65^{\circ} \mathrm{C}$, b) $\mathrm{H}_{2}, \mathrm{Pd}(\mathrm{OH})_{2 / \mathrm{C}}, \mathrm{THF} / \mathrm{MeOH} / \mathrm{H}_{2} \mathrm{O}$ 1: $78 \%$ 3: $75 \%$ over two steps.

The branched oligosaccharides were prepared using the same disaccharide donor but in this case a branching point was installed at the $4^{\text {th }}$ sugar by coupling of trisaccharide acceptor 23 
with thioglycoside 17 (see Scheme 2) to give tetrasaccharide $\mathbf{2 7}$ in $76 \%$ yield (see Scheme 5). Deprotection of the chloroacetyl group with $\mathrm{NaOMe} / \mathrm{MeOH}$ gave the tetrasaccharide acceptor $\mathbf{2 8}$ in $94 \%$ yield. A second glycosylation with disaccharide donor $\mathbf{2 0}$ gave the fully protected hexasaccharide 29 in $84 \%$ yield. Deprotection of the NAP ether with DDQ in $\mathrm{CH}_{2} \mathrm{Cl}_{2} / \mathrm{H}_{2} \mathrm{O}^{[16-17]}$ afforded the $\mathrm{C} 6-\mathrm{OH} 30$ in $75 \%$ yield.

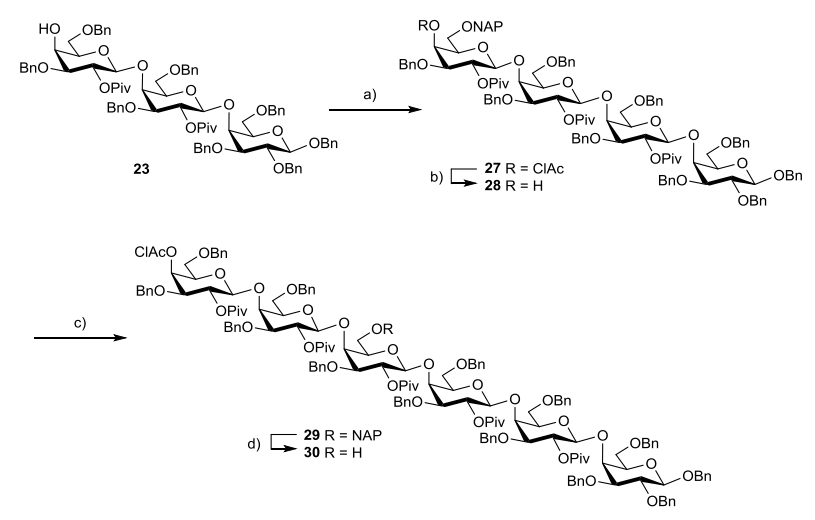

Scheme 5. a) 17, NIS/TESOTf, $\mathrm{MeCN} / \mathrm{CH}_{2} \mathrm{Cl}_{2},-40{ }^{\circ} \mathrm{C}, 76 \%$, b) $\mathrm{NaOMe} / \mathrm{MeOH}$, $0{ }^{\circ} \mathrm{C}, 94 \%$, c) 20 , NIS/TESOTf, $\mathrm{MeCN} / \mathrm{CH}_{2} \mathrm{Cl}_{2},-40{ }^{\circ} \mathrm{C}, 84 \%$, d) $\mathrm{DDQ}$ $\mathrm{CH}_{2} \mathrm{Cl}_{2} / \mathrm{H}_{2} \mathrm{O}, 75 \%$.

The hexasaccharide acceptor was glycosylated with five different donors (see ESI for details of their synthesis): a $\beta$-(1 $\rightarrow 4)$-linked D-digalactan 20, $\beta$ - $(1 \rightarrow 6)$-linked D-digalactan 31, $\alpha$ - $(1 \rightarrow 5)$-linked L-diarabinan 32 , D-galactose 33 , and L-arabinose 34 (see Scheme 6). The glycosylations with $n$-pentenyl and thioglycoside donors were promoted by NIS/TESOTf in a $1: 1$ $\mathrm{MeCN} / \mathrm{CH}_{2} \mathrm{Cl}_{2}$ mixture, whereas the glycosyl imidates were activated with TMSOTf in $\mathrm{CH}_{2} \mathrm{Cl}_{2}$. All of the reactions were performed at $-40{ }^{\circ} \mathrm{C}$ to enhance the stereoselectivity. All of oligosaccharides were isolated in over $70 \%$ yield.

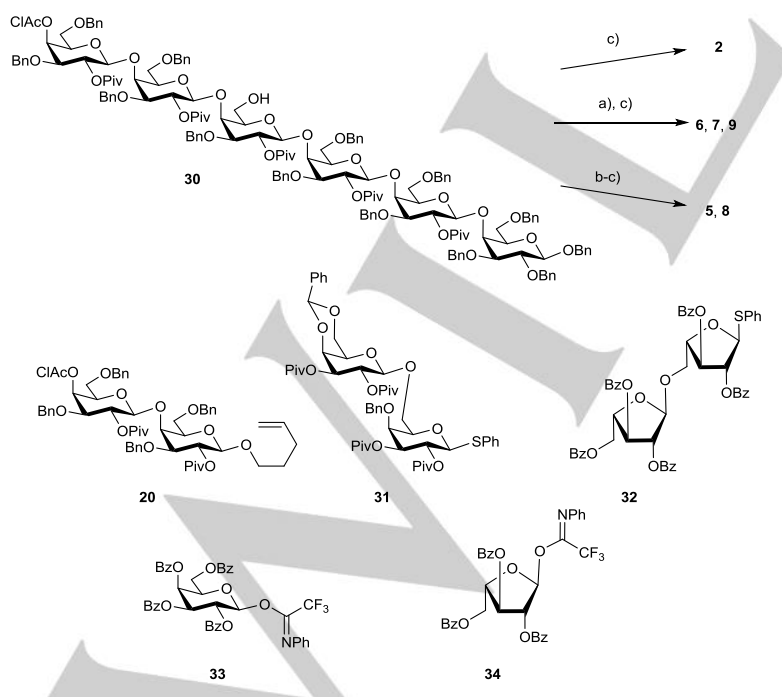

Scheme 6. a) 20/31/32, NIS/TESOTf, $\mathrm{MeCN} / \mathrm{CH}_{2} \mathrm{Cl}_{2},-40{ }^{\circ} \mathrm{C}, \mathbf{2 0}: 79 \%, 31$ : $82 \%$, 32: $83 \%$ b) 33/34, TMSOTf, $\mathrm{CH}_{2} \mathrm{Cl}_{2},-40{ }^{\circ} \mathrm{C}$ 33: $75 \%, 34: 81 \%$, c) i.
$\mathrm{Et}_{4} \mathrm{NOH}, \mathrm{MeOH} / \mathrm{THF}, 65^{\circ} \mathrm{C}$, ii. $\mathrm{H}_{2}, \mathrm{Pd}(\mathrm{OH})_{2} / \mathrm{C}, \mathrm{THF} / \mathrm{MeOH} / \mathrm{H}_{2} \mathrm{O}$ 2: $72 \%, 5$ $75 \%, 6: 73 \%, 7: 70 \%, 8: 68 \%, 9: 67 \%$.

Global deprotection of the seven branched oligosaccharides and linear hexasaccharide $\mathbf{3 0}$ was achieved by treatment with $\mathrm{Et}_{4} \mathrm{NOH}$ in refluxing THF followed by hydrogenolysis over $\mathrm{Pd}(\mathrm{OH})_{2} / \mathrm{C}$. The yields ranged between $67 \%$ and $75 \%$, which is acceptable considering the stability of the bulky pivaloyl groups. Milder conditions resulted in incomplete hydrolysis of the sterically hindered pivaloyl groups whereas stronger bases resulted in degradation due to elimination.

In the final substrate, an L-arabinose residue was introduced at the non-reducing end of hexasaccharide 29 via deprotection of the chloroacetyl group followed by TMSOTf-catalyzed glycosylation with perbenzoylated PTFAl donor 34 to afford heptasaccharide 35 (see Scheme 7). Global deprotection of the oligosaccharides with $\mathrm{Et}_{4} \mathrm{NOH}$ in refluxing $\mathrm{THF}$ followed by hydrogenolysis over $\mathrm{Pd}(\mathrm{OH})_{2} / \mathrm{C}$ afforded heptasaccharide 4 in $65 \%$ yield over two steps.

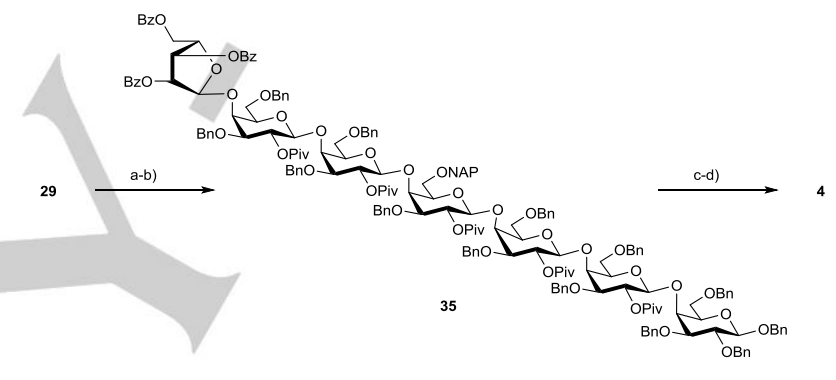

Scheme 7. a) $\mathrm{NaOMe} / \mathrm{MeOH}, 0{ }^{\circ} \mathrm{C}, 95 \%$, b) 34, TMSOTf, $\mathrm{CH}_{2} \mathrm{Cl}_{2},-40{ }^{\circ} \mathrm{C}$, $74 \%$, c) $\mathrm{Et}_{4} \mathrm{NOH}, \mathrm{MeOH} / \mathrm{THF}, 65^{\circ} \mathrm{C}$, d) $\mathrm{H}_{2}, \mathrm{Pd}(\mathrm{OH})_{2} / \mathrm{C}, \mathrm{THF} / \mathrm{MeOH} / \mathrm{H}_{2} \mathrm{O}, 65 \%$.

In order to demonstrate the usefulness of the synthetic galactans for probing carbohydrate-protein interactions, we used glycan array screening. Galactans 1-9 and selected commercial linear arabinans (DP 3, 5 and 8) used as controls (Megazyme, Bray, Ireland) were printed onto Slide $\mathrm{H}$ microarrays from Schott (Mainz, Germany). For immobilization, we used the hetero-bifunctional linker 2-( $N$-methyl-aminooxy)-1-ethanamine ${ }^{[18]}$ that was synthesized and used to amino-functionalize the oligosaccharides according to a modified protocol from literature. ${ }^{[19]}$ The conjugated oligosaccharides were desalted and printed using an ArrayJet Sprint microarrayer (ArrayJet, Roslin, UK) according to conditions modified from previous reports. ${ }^{[19-21]}$ Screening was performed essentially as previously reported ${ }^{[22]}$ for two monoclonal antibodies (MAbs LM5 and LM6) followed by a rabbit anti-mouse fluorescent secondary antibody, or by probing with a carbohydrate-binding module (CBM61) followed by a fluorescent anti-His antibody. The binding data can be seen in the Supporting Information and is presented in Table 1.

mAbs and CBM recognizing structural elements found in cell wall polysaccharides are important tools for studying plant fibers in situ with immunofluorescence spectroscopy. This technique has been applied to determine changes in cell wall polysaccharide distributions during plant development, for example. ${ }^{[23]}$ The rat monoclonal antibody LM5 is known to bind 
$\beta$-1,4-linked galactans, and has been generated by immunization of rats with a $\beta-1,4-\mathrm{Gal}_{4}-\mathrm{BSA}$ neoglycoprotein. ${ }^{[24]}$

The data in Table 1 clearly shows that LM5 exclusively binds the linear galactans 1-3. Branching is not tolerated and the fact that a terminal arabinan (oligosaccharide 4) eliminates binding shows that the LM5 epitope most probably involves the reducing end galactose residue. LM6, another rat monoclonal raised by immunization with a BSA neoglycoconjugate and popular for immunofluorescent microscopy of plant tissue is selective for arabinans and is included here as a control to rule out unspecific binding during the array screening. ${ }^{[25]}$ It has been demonstrated that $\mathrm{LM} 6$ requires at least three consecutive arabinose residues for binding and as expected, no binding to any of the galactans 1-9 can be detected with LM6, whereas binding to the linear arabinans is clearly detected.

Table 1. Microarray data for binding of LM5 antibody and CBM61 to the synthesised linear and branched galactans 1-9 as compared to controls (arabinans with DP3, DP5 and DP8 probed with LM6).

\begin{tabular}{ccccccccccccc} 
Compound & $\mathbf{1}$ & $\mathbf{2}$ & $\mathbf{3}$ & $\mathbf{4}$ & $\mathbf{5}$ & $\mathbf{6}$ & $\mathbf{7}$ & $\mathbf{8}$ & $\mathbf{9}$ & Ara3 & Ara5 & Ara8 \\
\hline \hline LM5 & 37 & 64 & 48 & 0 & 0 & 0 & 0 & 0 & 0 & 0 & 0 & 0 \\
LM6 & 0 & 0 & 0 & 0 & 0 & 0 & 0 & 0 & 0 & 86 & 80 & 100 \\
CBM61 & 0 & 0 & 0 & 0 & 0 & 0 & 0 & 0 & 0 & 0 & 0 & 0
\end{tabular}

CBM61, a carbohydrate-binding module from a Thermotoga maritima endo- $\beta-(1 \rightarrow 4)$-galactanase, has previously been shown to bind an unusual epitope related to a helical conformation of $\beta$ $(1 \rightarrow 4)$-D-galactan. ${ }^{[26]}$ Our studies show that neither linear nor branched oligogalactans are recognized by CBM61 when conjugated and immobilized on a microarray surface. The lack of binding is likely a result of the helical conformation being lost by branching and/or surface presentation.

In conclusion, a convergent strategy for $(1 \rightarrow 6)$-branched $\beta$-( $1 \rightarrow 4)$-D-galactans was developed and a small library of hepta- and octasaccharides has been prepared. The late-stage introduction of branching significantly reduces the overall number of steps and makes it possible to use different donors. The substrates have been used for the preparation of oligosaccharide microarrays and in addition to the results presented here, the oligosaccharides are expected to give new insight regarding the structure and function of pectic polysaccharides in the future.

\section{Acknowledgements}

We acknowledge financial support from the Danish Council for Independent Research and the Danish Strategic Research Council (GlycAct and SET4Future projects), from the Villum Foundation (PLANET project) and the Novo Nordisk Foundation (Biotechnology-based Synthesis and Production Research).
Keywords: Carbohydrate - Plant Cell Wall • Glycosylation • Oligosaccharide $\bullet$ Rhamnogalacturonan

[1] M. S. Doblin, F. Pettolino, A. Bacic, Funct. Plant Biol. 2010, 37, 357381.

[2] R. A. Burton, M. J. Gidley, G. B. Fincher, Nat. Chem. Biol. 2010, 6, 724-732.

[3] A. J. Voragen, G.-J. Coenen, R. Verhoef, H. Schols, Struct. Chem. 2009, 20, 263-275

[4] M. A. Laurent, P. Boulenguer, Food Hydrocoll. 2003, 17, 445-454

[5] D. Platt, A. Raz, J. Natl. Cancer Inst. 1992, 84, 438-442.

[6] H. Inohara, A. Raz, Glycoconj. J. 1994, 11, 527-532.

[7] P. Nangia-Makker, V. Hogan, Y. Honio, S. Baccarini, L. Tait, R. Bresalier, A. Raz, J. Natl. Cancer Inst. 2002, 94, 1854-1862.

[8] Z. Zhang, I. R. Ollmann, X.-S. Ye, R. Wischnat, T. Baasov, C.-H. Wong, J. Am. Chem. Soc. 1999, 121, 734-753.

[9] A. N. Zakharova, R. Madsen, M. H. Clausen, Org. Lett. 2013, 15, 18261829.

[10] For early examples of selective glycosylation of 3,4-unprotected galacose accepters, see: pH. Paulsen, K.-M- Steiger, Carbohydr. Res. 1987, 169, 105-125

[11] H. A. El-Shenawy, C. Schuerch, Carbohydr. Res. 1984, 131, 239-246.

[12] P. Kovac, R. B. Taylor, P. Kováč, Carbohydr. Res. 1987, 167, 153-173.

[13] F. W. Lichtenthaler, M. Oberthür, S. Peters, Eur. J .Org. Chem. 2001 3849-3869.

[14] M. P. DeNinno, J. B. Etienne, K. C. Duplantier, Tetrahedron Lett. 1995 36, 669-672.

[15] Y. Kobayashi,, M. Shiozaki, O. Ando, J. Org. Chem. 1995, 60, 25702580.

[16] H. Fuwa, S. Fujikawa, K. Tachibana, H. Takakura, M. Sasaki, Tetrahedron Lett. 2004, 45, 4795-4799.

[17] T. J. Boltje, C. Li, G.-J. Boons, Org. Lett. 2010, 12, 4636-4639.

[18] Mravec, J., S. K. Kracun, M. G. Rydahl, B. Westereng, F. Miart, M. H. Clausen, J. U. Fangel, M. Daugaard, P. Van Cutsem, H. H. D. Licht, H. Hofte, F. G. Malinovsky, D. S. Domozych, W. G. T. Willats, Development 2014, 141, 4841-4850.

[19] O. Bohorov, H. Andersson-Sand, J. Hoffmann, O. Blixt, Glycobiol, 2006 16, 21c-27c.

[20] N. H. Packer, M. A. Lawson, D. R. Jardine, J. W. Redmond, Glycoconj. J. 1998, 15, 737-747.

[21] S. K. Kracun, E. Clo, H. Clausen, S. B. Levery, K. J. Jensen, O. Blixt, J. Proteome Res. 2010, 9, 6705-6714.

[22] H. L. Pedersen, J. U. Fangel, B. McCleary, C. Ruzanski, M. G. Rydahl, M. C. Ralet, V. Farkas, L. von Schantz, S. E. Marcus, M. C. F Andersen, R. Field, M. Ohlin, J. P. Knox, M. H. Clausen, W. G. T. Willats, J. Biol. Chem. 2012, 287, 39429-39438.

[23] J. P. Moore, J. U. Fangel, W. G. T. Willats, M. A. Vivier, Annals Botany 2014, 114, 1279-1294; W. G. T. Willats, C. G. Steele-King, S. E. Marcus, J. P. Knox, Plant J. 1999, 20, 619-628.

[24] L. Jones, G. B. Seymour, J. P. Knox, Plant Physiol. 1997, 113, 14051412.

[25] W. G. T. Willats, S. E. Marcus, J. P. Knox, Carbohydr. Res. 1998, 308 , 149-152.

[26] M. Cid, H. L. Pedersen, S. Kaneko, P. M. Coutinho, B. Henrissat, W. G T. Willats, A. B. Boraston, J. Biol. Chem. 2010, 285, 35999-36009.

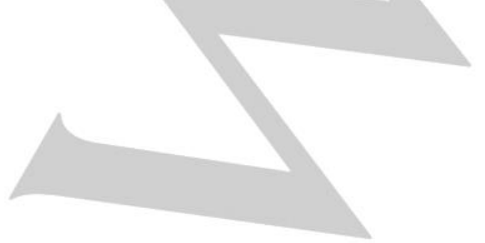




\section{COMMUNICATION}

We report the chemical synthesis of nine linear and branched galactan oligosaccharides related to the plant cell wall polysaccharide pectin. The target molecules will allow the detailed study of carbohydrate-protein interactions, as examplified for two $\mathrm{mAbs}$ and a CBM here.

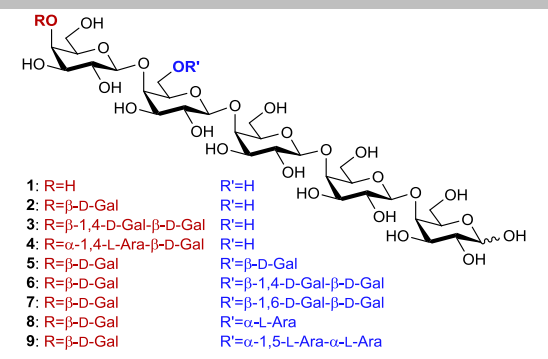

Mathias C. F. Andersen, ${ }^{[a]}$ Stjepan K. Kračun, ${ }^{[b]}$ Maja G. Rydahl, ${ }^{[b]}$ William G. T. Willats, ${ }^{[b, c]}$ and Mads $H$. Clausen ${ }^{\star[a]}$

Page No. - Page No.

Synthesis of $\beta-1,4$-linked galactan side chains of rhamnogalacturonan I 